\title{
Agricultural Subsidies and Rural Family Entrepreneurship-Empirical Analysis Based on Chinese Microdata
}

\author{
Jina Li \\ College of Economics, Jinan University, Guangzhou, China \\ Email: lijinayx@126.com
}

How to cite this paper: Li, J.N. (2018) Agricultural Subsidies and Rural Family Entrepreneurship-Empirical Analysis Based on Chinese Microdata. American Journal of Industrial and Business Management, 8, 963-984.

https://doi.org/10.4236/ajibm.2018.84066

Received: March 19, 2018

Accepted: April 25, 2018

Published: April 28, 2018

Copyright $\odot 2018$ by author and Scientific Research Publishing Inc. This work is licensed under the Creative Commons Attribution International License (CC BY 4.0).

http://creativecommons.org/licenses/by/4.0/

(c) (i) Open Access

\begin{abstract}
Using the data of Chinese household finance survey in 2011, this paper has used the binary regression model of discrete variables to examine the influence of agricultural subsidy policy on rural family entrepreneurial behaviors. Empirical research shows that agricultural subsidies significantly lower the probability of the rural family entrepreneurial behaviors. On average, every 1 per cent increase in agricultural subsidies would reduce the probability of rural family entrepreneurship by 15.6 percentage points. At the same time, the influence of agricultural subsidies on family entrepreneurial probability is heterogeneity: agricultural subsidies have significantly reduced the probability of rural family entrepreneurship in low-social network groups and non-main producing areas, but have not significantly reduced the probability of rural family entrepreneurship in high-social network groups and major grain-producing areas. Further study found that agricultural subsidies affect the transmission mechanism of rural family entrepreneurial probability: agricultural subsidies-raising agricultural income and reducing the probability of entrepreneurship. Finally, this paper puts forward that it should give full play to comparative advantage and implement regional differentiation subsidy strategy; we will vigorously develop inclusive finance to improve the rural credit environment.
\end{abstract}

\section{Keywords}

Agricultural Subsidy, Rural Family Entrepreneurial Behavior, Heterogeneity

\section{Introduction}

\subsection{Literature Review}

In the process of economic development, entrepreneurial activities play an im- 
portant role. On the micro level, entrepreneurial activity increases the flexibility of individual employment. On the macro level, entrepreneurship promotes the development of innovative economy. In 2015, Premier Li Keqiang put forward the work report of the government: "mass entrepreneurship and innovation" [1]. Therefore, our government attaches great importance to entrepreneurial activities.

Agriculture is the foundation of the national economy. Agricultural subsidy policy is one of the important agricultural policies that encourage farmers to engage in agricultural production. Since 2004, the government has invested a large amount of financial subsidies each year to promote the development of agricultural production. What is the policy effect of agricultural subsidy? This is a question worth studying.

Since the state attaches great importance to entrepreneurial activities and agricultural development, if farmers are engaged in agricultural production, they also carry out entrepreneurial activities. Will agricultural subsidies affect family entrepreneurship? If it does, what is the mechanism of action? This article tries to answer these questions.

\subsubsection{Literature Review on Agricultural Subsidies}

First, the research on agricultural subsidy mainly focuses on the effect of policy implementation. To sum up, it can be divided into agricultural subsidies for economic development and farmers' income, the impact on labor and agricultural production and agricultural subsidy externality research.

The effect of agricultural subsidy on economic development and farmer's income. Scholars have different opinions. Most scholars believe that agricultural subsidies play a positive role in increasing farmers' income and promote the development of rural areas in China (Zhao Menghan, 2010 [2]; Fan Baoxue, 2011 [3]). Some scholars believe that the agricultural subsidy policy to a certain extent, has a distorting effect on agricultural structure and agricultural products market, for example, agricultural subsidy policies reverse agricultural price fluctuations and agricultural machinery prices. Therefore, farmers do not enjoy the increase of income from agricultural subsidies and the benefits of economic development (Zhang Qiping, 2010 [4]; Gao Yuqiang, 2010 [5]; Zeng Fusheng, Zhu Qizhen, 2010 [6]; Wang Xiaoyun, Zhao Ling, 2010 [7]; He Shuquan, 2012 [8]; Li Jinshan, Xu Yue, 2015 [9]).

The effect of agricultural subsidy on rural labor transfer: Li Mingqiao and $\mathrm{Xu}$ Yan (2012) studied the relationship between agricultural subsidy policy and rural labor force. The results showed that the family farm subsidies will induce development transfer of money and more labor resources into higher economic benefit in non-agricultural production behavior, deviated from the agricultural subsidies to encourage farmers to agricultural production policy intentions [10]. Lv Wei et al. (2015) studied the relationship between agricultural machinery purchase subsidy and rural labor transfer in agricultural subsidies. The research results show that agricultural machinery is gradually replacing the labor force by increasing agricultural mechanization level and agricultural production effi- 
ciency [11].

Agricultural subsidies for agricultural production, the influence of Zhongcp, Chen Sanpan, Chang-Sheng Xu (2013) argues that the current agricultural subsidies have vague and extensive features, weakening signal function of subsidies, not play the role of obvious incentives to farmers to increase agricultural production in [12]. Sun Weiyan and Zhai Yinli (2016) pointed out that farmers' understanding of agricultural subsidy policies and the higher degree of satisfaction, the stronger the farmers' willingness to produce agricultural products [13]. Jiang Xiaomin (2017) [14], Xiaolin (2017) [15] et al. adopted the questionnaire survey of oil tea operators. It is concluded that agricultural subsidy has positive influence on the scale efficiency of peasant households and agricultural subsidy can affect the decision-making behavior of farmers' oil tea planting. Jiang Dongpo, Zhu Mande and Wuguo-Yong (2017) pointed out that agricultural subsidies distort wheat production to varying degrees and reduce the technical efficiency [16].

Agricultural subsidies the impact on the environment such as: Ling-Ling Hou, sun, Yue-Ying $\mathrm{Mu}$ (2012) through theoretical and empirical analysis, found that the implementation of the agricultural subsidy policy cause of increased use of chemical fertilizers, resulting in environmental pollution [17]. Yu Wei, Qi Yanbin and Yu Hua (2017) also further confirmed that agricultural subsidies distort the market of fertilizer elements and aggravate agricultural environmental pollution [18].

To sum up, the research on agricultural subsidies focuses on the agricultural subsidy policy on farmers' income, labor transfer, agricultural production behavior and efficiency, and the development of rural economy. To sum up, it is to focus on farmers, agriculture and rural areas, the "three rural" perspective, relatively few studies on non-agricultural perspectives. And scholars have not reached consensus on the policy effect of agricultural subsidies, which also indicates that there is still a lot of research space and research value.

\subsubsection{Literature Review on Entrepreneurship}

In terms of entrepreneurship, scholars have done a lot of research from different perspectives. It can be concluded that there are two kinds of existing researches, one is the research on the external factors of entrepreneurship, and the other is the research on the internal factors of entrepreneurship.

From the perspective of financial environment, Zhuhonggan and Kanglanyuan (2013) investigated the impact of financial environment and policy support on farmers' entrepreneurial intention. It is found that favorable financial environment and policy support in rural areas can help to improve farmers' entrepreneurial willingness [19]. In the context of Internet finance, Wangzimin and Cai Takinyi (2016) analyzed the background of Internet finance. Compared with small business owners, investors preferred to support the public start-up financing of working class [20]. Aokun (2016) pointed out that the liquidity constraint inhibits the entrepreneurial behavior of rural households [21]. Chen 
Yan and Cui Jing (2016) used micro data to analyze and verify that the phenomenon of "hybrid financing" existed in China's independent entrepreneurial families [22].

To study from the perspective of policy environment: Yang Yu (2013) from the theory and implementation path of fiscal law to promote entrepreneurship, an analysis was made on the problems of fiscal law in promoting entrepreneurship inadequate protection, structural imbalance, lack of practical problems such as unbalanced efficiency and policy, on the basis of this puts forward system Suggestions to promote the business [23]. Chen Gang (2015) systematically assessed the impact of government regulation on the probability of individual entrepreneurship. It is found that government regulation significantly reduces the probability of individual entrepreneurship and its influence on the probability of individual entrepreneurship is heterogeneous [24]. Ma Shuang and Meng Xiaoyu (2016) studied the impact mechanism of labor cost rising on the probability of the residents' entrepreneurship [25].

From the perspective of economic environment: Wuxiaoyu et al. (2014) found that the increase of housing price has different impacts on the entrepreneurial decision-making of the non-room population and the housing population [26]. Tian Bifei et al. (2014) adopted macro entrepreneurial data to study the impact of fdi on entrepreneurship. The results show that foreign direct investment has heterogeneity in the impact of international entrepreneurship and national entrepreneurship [27]. Tian Bifei and Chen Ziru (2016) studied how foreign direct investment affects domestic entrepreneurship in the provinces and between provinces [28].

From the perspective of social environment: will religious belief affect entrepreneurship? Ruanjung's equality (2014) and research show that religious belief does have an impact on entrepreneurship: there is a greater probability that religious believers will start a business than non-religious believers [29]. Research by Zhaopengfei and Wanghongjian (2015) also confirmed this claim. [30]. In addition, scholars have studied the influence of corruption regulation, social norms and other factors on entrepreneurial activities (Zhengxin, Zhouxianbo, 2017 [31]; Yu Swimming, Yang Xiaozhang, Zhang Ming; 2018 [32]).

\section{A review on the internal factors of entrepreneurship}

From entrepreneurial social capital research: mina etc. (2015), the study found that the social network significantly increase the probability of the urban and rural households to entrepreneurship, and the effect and the mechanism of action of inner heterogeneity exists between urban and rural households [33]. Zhao Pengfei and Wanghongiian (2015) analyzed the impact of social capital on family entrepreneurship, and found that families with rich social capital were more willing to start their own businesses.

To study from the perspective of resource entrepreneurship: Mei-Yuliu (2013), explore the new generation migrant workers of entrepreneurial motivation resources and business model, the relationship between the research 
pointed out that entrepreneurship resources affect the choice of the entrepreneurs entrepreneurship model [34]. Li Jiang (2016) systematically studied the relationship between China's unique forms of property rights and family entrepreneurship [35]. Zhao Pengfei et al. (2015) analyzed the impact of human capital endowment on urban and rural household entrepreneurship. It is found that the influence of human capital on entrepreneurship is heterogeneity among urban and rural families [30].

From the perspective of risk perspective, Zhaopengfei and Wanghongjian (2015) found that the families of the risk-loving respondents were more inclined to start a business by empirical analysis [30]. Yang $\mathrm{Na}$ (2015) examined the relationship between the subjective risk attitude and entrepreneurial choice of entrepreneurs themselves. The empirical results show that people with different risk preferences will also have different entrepreneurial industries when making their choice. In addition, the degree of risk aversion is inversely related to the income of industrial and commercial start-ups, and there is no inverted u-shaped relationship with agricultural start-up income [36].

Starting from the perspective of family background: Xuyuwei et al. (2015) studied the relationship between social endowment insurance and rural family entrepreneurial decision making. The study found that because social endowment insurance can provide a basic guarantee for the health of the family, the family's risk aversion to entrepreneurship is reduced. Therefore, participating in social endowment insurance has a positive promoting effect on family entrepreneurship [37]. Li Xuelian (2015) analyzed the relationship between civil servant family background and entrepreneurial vigor. Further analysis indicates that the motive of rent-seeking may be the real reason for the high entrepreneurial vitality of the civil servant family [38].

\subsubsection{Agricultural Subsidies and Off-Farm Production}

According to Barnum and Squire (1979) [39], the "new classical peasant economic theory" developed by Singh et al. (1986) [40], the farmers are aiming at maximizing the overall utility of the family. Agricultural production behavior and non-agricultural production should be considered in the analysis of farmer's behavior choice. Agricultural policy is the important factor that affects farmer's agricultural labor input. As a means of financial transfer payment, agricultural subsidy reflects the policy orientation of government to agricultural development. When analyzing the government's agricultural subsidy policy, we should not only consider its impact on agricultural production behavior, but also consider the impact on non-agricultural production behavior.

There is no consensus on the influence of agricultural subsidies on the choice of farmers' behavior. Some scholars believe that agricultural subsidies have a negative effect on farmers' off-farm production. For example, Ahearn et al. (2006) showed that any agricultural subsidy can lead to a decline in non-agricultural labor participation rate [41]. Kym Anderson (2009) demonstrated this view from a reverse perspective. They argue that agricultural subsi- 
dies help reduce the impact of non-agricultural industries on agriculture. [42]. Wu Liancui (2012) using Tobit model, investigates the supply of agricultural subsidies to farmers to non-agricultural labor time, results show that the grain subsidy policy to farmers non-farm labor time supply has significant negative effects, namely food subsidies dampened the enthusiasm of peasants for non-agricultural production [43]. Zeng Yu (2016) through the theoretical and empirical analysis of agricultural subsidy policy benefit, it is concluded that agricultural subsidies for farmers to take more than money, increasing agricultural input, reducing non-farm labor input [44].

Some scholars hold the opposite view. Hennessy (2008), for example, qualitatively analyzed the relationship between agricultural subsidies and off-farm production. The results show that the decoupling subsidy will increase the professional level of non-agricultural production [45]. James et al. (2005) used microdata to quantitatively analyze the effect of agricultural subsidies on the enthusiasm of farmers. He thinks that even if farmers give up their grain production, they will get a transfer income. Therefore, food subsidies will lead some farmers to give up their crops and induce farmers to make non-agricultural production. Ming-Qiao Li (2012), the results indicate that such as farm subsidies will induce development family subsidies for agricultural production and labor input to the non-agricultural industries, deviated from the agricultural subsidies to encourage farmers to agricultural production policy intentions [10]. Lvwei et al. (2015) studied the relationship between agricultural machinery purchase subsidy and rural labor transfer in agricultural subsidies. The research results show that agricultural machinery is gradually replacing the labor force by increasing agricultural mechanization level and agricultural production efficiency [11]. Moyue and Wangyixuan (2008) analyzed the effect of agricultural subsidy policy. The results show that agricultural subsidies will have an impact on the agricultural sector, which will lead to lower prices of agricultural products and fishery products. On the other hand, agricultural subsidies will have an impact on the non-agricultural production sector, but the impact will be less than that of the agricultural sector [46].

\subsection{The Theoretical Analysis}

From the above research, it can be concluded that the scholars' opinions on agricultural subsidy policy are divided on the choice of farmers' agricultural production and non-agricultural production. Differences in data and research perspectives and methods are also likely to be one of the reasons for the disagreement. In this paper, the following deficiencies are considered:

First of all, the existing literature is only a general study of the impact of agricultural subsidies on agricultural production and non-agricultural production. But the farmer's off-farm production behavior includes but not limited to go out to work and carry on independent business. How do agricultural subsidies affect these specific off-farm production practices, especially the entrepreneurial beha- 
vior of farmers?

Second, most of existing literatures on the study area with only one or a few regions as the research object, the data also is part of the regional sample survey data, the more the lack of a wider range and a nationwide study. However, due to the different economic development level and geographical factors, the study of individual regions is not representative, so it may reduce the credibility of the research conclusion.

Through the above analysis, this paper proposes the following hypothesis:

Through the above analysis, this paper proposes the following hypothesis:

- Hypothesis 1: agricultural subsidies reduce the probability of family entrepreneurship.

- Hypothesis 2: the influence of agricultural subsidy on family entrepreneurial probability has heterogeneity in the social network group.

- Hypothesis 3: the influence of agricultural subsidy on family entrepreneurial probability is heterogeneous in main producing areas and non-main producing areas.

- Hypothesis 4: agricultural subsidies reduce the probability of family entrepreneurship by increasing agricultural income.

\section{Model and Data}

\subsection{The Basic Model}

The core issue of this study is how agricultural subsidies affect family entrepreneurship. Family entrepreneurship is a binary variable, so we use the binary regression model to study the relationship between agricultural subsidy and family entrepreneurial probability. Its regression model is as follows:

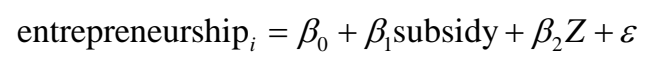

The explanatory variable is the discrete variable, and 1 represents the family entrepreneurship. 0 indicates that there is no entrepreneurship, and the explanatory variable is agricultural subsidy; As control variables, including gender, age, level of education, marital status, family population, social networks, family income levels, the formal financial, private lending and regional variables, such as for the random error term.

\section{Variable Definition Description}

Agricultural subsidy: In this article, according to the item B1008 CHFS2011 years questionnaire "monetary subsidies amount" and B1010 "to the market price discount, how much are these real value about" total as "wide caliber" agricultural subsidies, taking natural logarithms as explanatory variables in the model. In addition, in the robustness test, the "narrow gauge" agricultural subsidy, namely the monetary subsidy, is used as the explanatory variable in the model.

Agricultural income: The monthly average agricultural income after agricultural subsidy was excluded. 
Gender: Male, gender $=1$, otherwise 0 .

Age: Age of interviewees

Level of education: In the absence of school, it is 0 , the first class education is 1 , the medium education is 2 , the higher education is 3 , and the peat is 4 .

Marital status: If there is a spouse, the marital status $=1$, otherwise it is 0 .

Risk attitude: Risk preference, risk attitude is 1, risk neutral, 2, risk aversion is 3.

Economic expectation: If the economy is expected to get better, the economy is expected to be 0 and the same is 1 , otherwise it will be 2 .

Social network: Holiday and red and white wedding income and expenditure combined to take the logarithm.

The number of households: Number of family members

Informal financial: Other channels borrow money to take the natural log.

Household income: The monthly average of household income takes the natural log.

Formal financial: Whether there is a loan for industrial and agricultural production and operation, there is a bank loan of 1 , otherwise it is 0 .

Region: The eastern region is 0 , the central region is 1 , and the western region is 2 .

\subsection{Data Interpretation}

This paper uses data from the China Household Finance Survey (CHFS) of the China Household Finance Survey and research center to study the impact of agricultural subsidies on family entrepreneurship. The variables used in this article are all from the same data source, which can guarantee the consistency of the data, making the research conclusion of this paper more robust.

Family entrepreneurship: referring to the research of Paulson and Townsend (2004), this paper regards rural households as entrepreneurial activities [47]. This is also the way of dealing with the definition of family entrepreneurship in the existing literature [48]. Li Xuelian et al., 2015 [38]; Zhang Bo et al., 2015 [33]. In terms of the data used in this paper, according to the item B2001 in the questionnaire of CHFS2011, the subjects were divided into two groups: select the first option, namely, B2001 $=1$. Select the second option, B2001 $=2$, for the non-family business group.

Agricultural subsidies: most of the agricultural subsidies studied in the existing literature are agricultural subsidy data published by government websites (Caoshuai et al., 2012 [49]; Wang Ou et al., 2014 [50]); at the micro level, the data of agricultural subsidies involved in the questionnaire are mostly defined (Yang Xiaojing, 2010 [51] Wu Haitao et al., 2015 [52]. In this article, according to the item B1008 CHFS2011 years questionnaire "monetary subsidies amount" and B1010 "to the market price discount, how much are these real value about" total as "wide caliber" agricultural subsidies, taking natural logarithms as explanatory variables in the model. In addition, in the robustness test, the "narrow 
gauge" agricultural subsidy, namely the monetary subsidy, is used as the explanatory variable in the model.

Individual characteristics: the employment behavior of individual workers will be affected by their own human capital endowment. Firstly, many empirical studies have confirmed that farmers with high human capital endowments will tend to engage in non-agricultural industries and reduce agricultural labor input [53]. Therefore, gender, age, education degree and marital status were selected as individual characteristic variables. Yang $\mathrm{Na}$ (2015) confirmed that people who prefer risk are more likely to engage in entrepreneurial projects [36]. Therefore, this paper also selects two variables that reflect the subjective attitude of interviewees: risk attitude and economic expectation.

In addition to individual characteristic variables, this paper also selects family characteristic variables as follows:

Social network: numerous studies show that entrepreneurs' social network can help them get needed information in the process of entrepreneurship, resources, knowledge and ability, etc., has successfully created a new business, new business and get sustainable development. Ma Guangran and Yang Enyan (2011) study on family holidays and red and white wedding expenses as proxy variables of social network [54]. But this paper argues that family holidays and funerals spending and income of the total reflected more family social network, so its natural logarithm as the proxy variable of social network, this paper expects its will be good for family business.

Formal finance: financing constraint is an important factor restricting the behavior of entrepreneurship, and scholars at home and abroad have been studying it for a long time. Buera (2009) verifies the importance of credit constraint on entrepreneurial activity from the perspective of data [55]. Liu Yan (2015) also studied the impact of credit constraints on entrepreneurship from the micro level [56]. In this paper, we refer to the existing literatures to find out whether the households with industrial and agricultural production loans are the proxy variables of formal finance. But given the rural financial development level is relatively high, farmers with entrepreneurship more often between borrowing from relatives and friends, so this article is expected to formal financial is not necessarily a significant impact on business.

Private lending: due to the relatively backward level of rural financial development, farmers can have less assets to be mortgaged, and Banks will also lend prudently on the basis of risks and other considerations. Therefore, it may be difficult for rural households to obtain bank loans for industrial and agricultural production. Rural areas are more rural, so if there is a funding gap, they may be more likely to borrow through non-financial channels such as friends and relatives. This informal financial borrowing could exceed normal financial borrowing, so this article will channel borrowing from other natural logarithm as proxy variable of private lending, expects the folk lending will have a positive influence on family business. 
In order to control the influence of regional differences on regression results, regional variables were added to the model.

In the analysis of the impact mechanism of the third part of agricultural subsidy on family entrepreneurship, this paper has added the income of family agriculture. Family agricultural income is the monthly average of agricultural income derived from natural log. According to the results of the CHFS2011 survey, 2545 households were involved in agricultural production and agricultural subsidies, of which 226 were self-employed, and $8.89 \%$ were entrepreneurs. According to the results of the survey, the probability of starting a business with unsubsidized households is $9.35 \%$, which is 0.46 percentage points higher than that without subsidy. Concrete from the provinces, 2011 Chinese families in the business of agricultural production and the subsidy cases rate of the top three provinces are respectively: (16.05\%), Henan, Hubei (10.47\%) and Jiangsu $(9.77 \%)$. The three provinces with the highest rate of entrepreneurship are Beijing (0.23\%), Shaanxi (0.70\%)and Gansu (0.93\%). From Table 1, we can see: The mean value of the respondents' gender was 0.627 , indicating that the majority of the respondents were male. The average age is about 51 , and the average education level is education. The majority of respondents had spouses; the mean of risk attitude is 2.53 , indicating the proportion of risk aversion is very high; The average economic forecast of respondents is 0.179 , indicating that most people are optimistic about China's economic development. The subsidy variables and family characteristic variables in Table 1 are shown in natural logarithms, so we will not analyze them in detail.

Table 1. Main variables and descriptive statistics.

\begin{tabular}{|c|c|c|c|c|}
\hline variable & mean & Standard error & Minimum & Maximum \\
\hline entrepreneurship & 0.090 & 0.286 & 0 & 1 \\
\hline Income & 940.111 & 4919.671 & 0 & 250,000 \\
\hline Subsidy & 719.919 & 7277.662 & 0 & 337,500 \\
\hline Gender & 0.627 & 0.484 & 0 & 1 \\
\hline Age & 51.692 & 12.427 & 17 & 92 \\
\hline Education & 1.34 & 0.782 & 0 & 3 \\
\hline Marriage & 0.917 & 0.276 & 0 & 1 \\
\hline Attitude & 2.532 & 0.697 & 1 & 3 \\
\hline Expectation & 0.179 & 0.478 & 0 & 2 \\
\hline Social & 2215.055 & 5974.125 & 0 & 204,500 \\
\hline Population & 4.060 & 1.688 & 1 & 18 \\
\hline Informal & $27,088.7$ & $88,066.49$ & 0 & $1,100,000$ \\
\hline Total income & 1591.034 & 8214.33 & 0 & $420,166.7$ \\
\hline Formal & 0.069 & 0.253 & 0 & 1 \\
\hline Region & 1.036 & 0.772 & 0 & 2 \\
\hline
\end{tabular}

Data source: CHFS survey data. 


\section{The Empirical Analysis}

\subsection{Model Estimation Results and Analysis}

This paper makes a regression analysis on the family business choice equation by agricultural subsidy. Regression results as shown in Table 2: Equation (1) is the sample data of agricultural subsidies for the return of the family business as a result, the Equations (2)-(5), respectively, to "high social network group", "low social network group", major grain-producing areas and grain of producing samples of regression results. The regression results are all the marginal effects of variables.

Table 2. Regression result of agricultural subsidy and family business relationship.

\begin{tabular}{|c|c|c|c|c|c|}
\hline variable & Equation (1) & Equation (2) & Equation (3) & Equation (4) & Equation (5) \\
\hline \multirow{3}{*}{ subsidies } & $-0.156^{* *}$ & -0.126 & $-0.224^{* *}$ & -0.087 & $-0.312^{* *}$ \\
\hline & $(0.072)$ & $(0.121)$ & $(0.103)$ & $(0.087)$ & $(0.125)$ \\
\hline & -0.015 & -0.246 & -0.031 & 0.018 & 0.493 \\
\hline \multirow[t]{2}{*}{ gender } & $(0.197)$ & $(0.323)$ & $(0.308)$ & $(0.221)$ & $(0.620)$ \\
\hline & 0.004 & 0.008 & 0.004 & 0.007 & -0.020 \\
\hline \multirow[t]{2}{*}{ age } & $(0.008)$ & $(0.013)$ & $(0.011)$ & $(0.009)$ & $(0.021)$ \\
\hline & 0.214 & $0.391^{\star}$ & 0.222 & 0.234 & 0.121 \\
\hline \multirow[t]{2}{*}{ education } & $(0.131)$ & $(0.235)$ & $(0.188)$ & $(0.152)$ & $(0.251)$ \\
\hline & -0.056 & -0.166 & -0.075 & 0.112 & -0.312 \\
\hline \multirow[t]{2}{*}{ marriage } & $(0.310)$ & $(0.425)$ & $(0.540)$ & $(0.424)$ & $(0.744)$ \\
\hline & 0.088 & -0.215 & $0.488^{* * *}$ & 0.082 & 0.247 \\
\hline \multirow[t]{2}{*}{ attitude } & $(0.117)$ & $(0.189)$ & $(0.177)$ & $(0.145)$ & $(0.298)$ \\
\hline & 0.132 & -0.354 & 0.324 & 0.170 & -0.224 \\
\hline \multirow[t]{2}{*}{ expectation } & $(0.192)$ & $(0.296)$ & $(0.229)$ & $(0.240)$ & $(0.333)$ \\
\hline & $0.174^{\star *}$ & 0.142 & $0.412^{* * *}$ & $0.250^{\star *}$ & -0.099 \\
\hline \multirow[t]{2}{*}{ social } & $(0.078)$ & $(0.192)$ & $(0.157)$ & $(0.101)$ & $(0.155)$ \\
\hline & $0.165^{\star \star \star}$ & 0.111 & $0.230^{\star \star *}$ & $0.167^{\star \star *}$ & 0.017 \\
\hline \multirow[t]{2}{*}{ population } & $(0.048)$ & $(0.089)$ & $(0.068)$ & $(0.059)$ & $(0.093)$ \\
\hline & $0.406^{\star * *}$ & $0.461^{\star * *}$ & $0.453^{* * *}$ & $0.393^{* * *}$ & $0.710^{* * *}$ \\
\hline \multirow[t]{2}{*}{ Informal } & $(0.062)$ & $(0.080)$ & $(0.096)$ & $(0.072)$ & $(0.173)$ \\
\hline & -0.082 & -0.136 & -0.113 & $-0.177^{\star}$ & $0.233^{*}$ \\
\hline \multirow[t]{2}{*}{ income } & $(0.072)$ & $(0.088)$ & $(0.117)$ & $(0.103)$ & $(0.136)$ \\
\hline & 0.080 & $0.674^{\star}$ & -0.460 & 0.267 & -0.263 \\
\hline \multirow[t]{2}{*}{ formal } & $(0.246)$ & $(0.351)$ & $(0.439)$ & $(0.297)$ & $(0.452)$ \\
\hline & $-0.328^{\star *}$ & $-0.831^{\star * *}$ & -0.079 & $-0.368^{*}$ & 0.145 \\
\hline \multirow[t]{2}{*}{ region } & $(0.135)$ & $(0.252)$ & $(0.178)$ & $(0.199)$ & $(0.305)$ \\
\hline & $-5.451^{\star \star \star}$ & -3.846 & $-8.790^{* * *}$ & $-5.987^{\star * *}$ & $-7.301^{\star * *}$ \\
\hline Constant & $(1.357)$ & $(2.434)$ & $(2.031)$ & (1.686) & $(2.659)$ \\
\hline observation & 435 & 174 & 261 & 305 & 130 \\
\hline
\end{tabular}




\subsubsection{Explain the Impact of Variables on Family Entrepreneurship}

It can be seen from the regression results of Equation (1) in Table 2 that the agricultural subsidy is negative at the significance level of 5\%, indicating that the agricultural subsidy significantly reduces the probability of family entrepreneurship. In particular, for every 1 percent increase in agricultural subsidies, the probability of family entrepreneurship dropped by 15.6 percent. The possible explanation is that agricultural subsidies will encourage farmers to increase agricultural inputs and continue agricultural production. Is limited because of family resources and labor force, more into agricultural production Significant effects due to the social networks of family business, so according to family social network of the sample data is divided into "high social network group" and "low social network group" two samples for the return of the equations of Equations (2) and (3). In particular, if the social network owned by the family is higher than the sample mean, it is classified as the "high social network group". If it is below the average of the sample, it belongs to the "low social network group". It can be seen from the regression results of the second and third column that the influence of agricultural subsidy on the family entrepreneurial probability of the high and low social network groups is heterogeneity. Specific to see farm subsidies in the "low social network group" is still on the 5\% significance level is negative, and agricultural subsidies to family business probability compared to the marginal effect of the whole sample increased by $6.8 \%$; but agricultural subsidies have become less prominent in the "high social network". Possible explanation is: in the low social network in the family, the available social resources is less, because of the existence of start-up capital threshold of farm subsidies will not increase the probability of its business, but will enhance the enthusiasm of agricultural production. But in the high social network group, as a result of the family can use of social resources is more, this means that the venture capital channels may be more, agricultural subsidies for will not strengthen the enthusiasm of agricultural production, so will not significantly reduce the probability of entrepreneurship.

In China there are major grain-producing areas and non-major grain-producing areas. Major grain-producing areas include Liaoning, Hebei, Shandong, Jilin, Inner Mongolia, Jiangxi, Hunan, Sichuan, Henan, Hubei, Jiangsu, Anhui and Heilongjiang provinces. The rest of the provinces are non-major grain producing areas. Major grain-producing areas and grain of grain number and amount and increase subsidies in the agricultural subsidies would be different, in this paper, the suspect agricultural subsidies influence on family business probability possible differences in different regions. Therefore, the sample data was divided into two sub-samples of the main grain-producing region and the non-main producing region of grain, and the regression of Equation (4) and Equation (5) was carried out. Regression results show that in food producing, agricultural subsidies to family business on $5 \%$ significance level is negative, and agricultural subsidies to family business the marginal effect of probability doubled compared to the whole sample. That is, in the non-major 
grain-producing areas, agricultural subsidies have significantly reduced the probability of family entrepreneurship. In the main grain-producing areas, the impact of agricultural subsidies on family entrepreneurial probability is not significant. Possible explanation is: in the major grain producing areas, agricultural laborers' to more engaged in agricultural production activities, and in food producing, people more non-agricultural production, so agricultural subsidies proportion of the same change on the marginal effect of entrepreneurial probability in food producing will be more obvious. To some extent, the effect of agricultural subsidy policy in major grain-producing areas needs to be further improved.

\subsubsection{Influence of Control Variables on Family Entrepreneurship}

From the perspective of individual characteristic variables, the respondents were positive in the "high social network group" in the "high social network group" at $10 \%$, namely, the higher the degree of education, the greater the probability of starting a business. However, the risk attitude is positive in the "low social network group" at the significance level of 5\%, namely, the head of the household is the risk appetite, and the family is more likely to start a business. In addition, other individual characteristic variables did not show significant performance. This is different from the results obtained in the existing literature.

From the perspective of family characteristic variables, the social network is positive at the significance level of $5 \%$ in the regression of the whole sample regression and the regression of the sub-samples in the main grain-producing areas. However, in the "high social network group" and the food production area is not significant. Family population in all the samples and the low social network group and in the major grain producing areas is positive in the $1 \%$ significance level, the more likely explanation is that the number of family, the more labor force can be used for business, and thus more conducive to the family business.

Family income level variables only in major grain producing areas and grain of alternation alternate is significant in $10 \%$ significant level, but in major grain producing areas to improve their family income will reduce the probability of family business, and in food producing is just the opposite. Private lending in all the regression was positive in the significance level of $1 \%$, while formal finance only showed significant performance in the "high social network group", and other regression results were not significant.

Possible explanation: due to the limited level of rural financial development, there is a credit constraint on family entrepreneurship, so it can alleviate this credit constraint by borrowing from relatives and other folk. But in high social network in the family, their access to social capital, all kinds of information is more, so the opportunity to get a bank loan is bigger, so formal financial helps the family business. The regional variables in the whole sample regression, the "high social network group" and the main grain producing areas were realized significantly, which was not significant in the other regression results.

By the above analysis we can draw the following conclusions: first, agricultural 
subsidies significantly reduces the probability of family business, the empirical results verified the hypothesis 1: agricultural subsidies to reduce the probability of family business. Second agricultural subsidies significantly reduced the low social network group and food of producing probability of family business, but did not significantly reduce the "high social network group" and the family business probability of major grain producing areas. The results respectively verify the hypothesis 2 and hypothesis 3 of this article.

\subsection{Analysis of the Mechanism of Agricultural Subsidies Affecting Family Entrepreneurship}

Our country's agricultural subsidy policy has experienced the change from ensuring food security to food security and increasing the income of farmers. If such policies are effective, agricultural subsidies should have a significant positive effect on farm incomes. The increase in agricultural income will enable farmers to invest more in agricultural production. Meanwhile, the resources of the family are limited. More agricultural production means that farmers reduce off-farm production and reduce the probability of family business. Therefore, this paper argues that the effect of agricultural subsidies on family entrepreneurship is through: agricultural subsidies-raising agricultural income-reducing family entrepreneurship. The following article will verify the transmission mechanism of this kind of agricultural subsidy.

The analysis of the previous article shows that agricultural income is the core of agricultural subsidies to inhibit the family entrepreneurial transmission mechanism. If such conduction mechanism exists, then agricultural income variables will be added to Equation (1), then the variable of agricultural subsidy will become insignificant. On the contrary, its significance remains unchanged. The Equation (1) to Equation (3) in Table 3 is obtained by adding agricultural income to Equations (1)-(3) in Table 2.

From the estimation results of Equation (1), it can be seen that agricultural subsidies become no longer significant after the agricultural income is added, indicating that the real impact on the family entrepreneurial probability is the agricultural income. However, the coefficient of agricultural income is negative, which is consistent with the impact of agricultural subsidies on the probability of family entrepreneurship. It also proves that the increase of agricultural income will reduce the probability of family entrepreneurship.

The result of Equation (2) is similar to Equation (1). After joining family farm income, agricultural subsidies less significant, but the direction of agricultural income and significant effect is negative, the agricultural subsidies increase the family income, promote the household spending on agriculture, to reduce the probability of family business.

Equation (3) after adding agricultural income, agricultural subsidies, becomes no longer significant, although consistent with agricultural subsidies. The regression results of the three equations show that agricultural subsidies have verified the above transmission mechanism by raising the probability that the family 
Table 3. The regression results impact mechanism analysis.

\begin{tabular}{|c|c|c|c|}
\hline variable & Equation (1) & Equation (2) & Equation (3) \\
\hline \multirow[t]{2}{*}{ subsidies } & -0.107 & -0.146 & -0.173 \\
\hline & $(0.074)$ & $(0.117)$ & $(0.140)$ \\
\hline \multirow[t]{2}{*}{ gender } & 0.021 & -0.099 & 0.507 \\
\hline & $(0.203)$ & $(0.325)$ & $(0.538)$ \\
\hline \multirow[t]{2}{*}{ age } & 0.005 & 0.015 & -0.012 \\
\hline & $(0.009)$ & $(0.012)$ & $(0.022)$ \\
\hline \multirow[t]{2}{*}{ education } & 0.218 & 0.254 & 0.036 \\
\hline & $(0.140)$ & $(0.206)$ & $(0.253)$ \\
\hline \multirow[t]{2}{*}{ marriage } & -0.119 & -0.248 & -0.644 \\
\hline & $(0.318)$ & $(0.550)$ & $(0.669)$ \\
\hline \multirow[t]{2}{*}{ Attitude } & 0.063 & $0.420^{* *}$ & 0.179 \\
\hline & $(0.116)$ & $(0.168)$ & $(0.306)$ \\
\hline \multirow[t]{2}{*}{ expectation } & 0.162 & 0.348 & -0.164 \\
\hline & $(0.200)$ & $(0.243)$ & $(0.395)$ \\
\hline \multirow[t]{2}{*}{ Population } & $0.180^{* * *}$ & $0.246^{\star * *}$ & 0.024 \\
\hline & $(0.050)$ & $(0.077)$ & $(0.109)$ \\
\hline \multirow[t]{2}{*}{ informal } & $0.418^{\star * *}$ & $0.521^{\star * *}$ & $0.746^{* * *}$ \\
\hline & $(0.063)$ & $(0.107)$ & $(0.186)$ \\
\hline \multirow[t]{2}{*}{ income } & $-0.226^{*}$ & $-0.440^{*}$ & -0.464 \\
\hline & $(0.126)$ & $(0.231)$ & $(0.322)$ \\
\hline \multirow[t]{2}{*}{ total income } & 0.031 & 0.159 & $0.607^{\star}$ \\
\hline & $(0.118)$ & $(0.198)$ & $(0.310)$ \\
\hline \multirow[t]{2}{*}{ Formal } & 0.054 & -0.668 & -0.555 \\
\hline & $(0.254)$ & $(0.476)$ & $(0.515)$ \\
\hline \multirow[t]{2}{*}{ social } & $0.162^{\star *}$ & $0.320^{* *}$ & -0.044 \\
\hline & $(0.078)$ & $(0.156)$ & $(0.156)$ \\
\hline \multirow[t]{2}{*}{ Constant } & $-5.081^{\star \star \star}$ & $-8.520^{\star * \star}$ & $-8.427^{\star * \star}$ \\
\hline & $(1.320)$ & (1.977) & $(2.778)$ \\
\hline Observation & 423 & 225 & 116 \\
\hline
\end{tabular}

Note: ${ }^{* *},{ }^{* *}$ and ${ }^{*}$ are significant at the significance level of $1 \%, 5 \%$ and $10 \%$ respectively; The Numbers in brackets are standard errors.

will start a business by raising the income of family agriculture. This is the hypothesis 4: agricultural subsidies reduce the probability of family entrepreneurship by raising agricultural income.

\section{Robustness Test}

In this paper, we verify the robustness of agricultural subsidies to family entrepreneurial probability by replacing variables and data classification. In terms of substitution variables, agricultural subsidies are further divided into "wide aper- 
ture" agricultural subsidies and "narrow" agricultural subsidies. "Wide-aperture" agricultural subsidies refer to both monetary and in-kind subsidies. "Narrow caliber" agricultural subsidies refer only to monetary subsidies. The subsidies used in the previous article are "wide aperture" farm subsidies, which are now replaced by "narrow" agricultural subsidies, and the equations in Table 2 are again returned. The regression results are shown in Table 4.

The regression results from Equation (1) to Equation (5), you can see that will be replaced by "wide caliber" agricultural subsidies "narrow caliber" agricultural

Table 4. The regression results impact mechanism analysis.

\begin{tabular}{|c|c|c|c|c|c|}
\hline variable & Equation (1) & Equation (2) & Equation (3) & Equation (4) & Equation (5) \\
\hline \multirow[t]{2}{*}{ subsidies } & $-0.139^{*}$ & -0.111 & $-0.213^{\star *}$ & -0.087 & $-0.341^{\star * *}$ \\
\hline & $(0.074)$ & $(0.123)$ & $(0.106)$ & $(0.086)$ & $(0.130)$ \\
\hline \multirow[t]{2}{*}{ gender } & -0.014 & -0.215 & -0.099 & 0.019 & 0.422 \\
\hline & $(0.201)$ & $(0.322)$ & $(0.314)$ & $(0.221)$ & $(0.610)$ \\
\hline \multirow[t]{2}{*}{ age } & 0.005 & 0.007 & 0.008 & 0.007 & -0.012 \\
\hline & $(0.008)$ & $(0.013)$ & $(0.011)$ & $(0.009)$ & $(0.021)$ \\
\hline \multirow[t]{2}{*}{ education } & $0.274^{* *}$ & $0.396^{*}$ & 0.295 & 0.234 & 0.344 \\
\hline & $(0.138)$ & $(0.235)$ & $(0.193)$ & $(0.152)$ & $(0.307)$ \\
\hline \multirow[t]{2}{*}{ marriage } & -0.039 & -0.179 & -0.144 & 0.112 & -0.313 \\
\hline & $(0.325)$ & $(0.431)$ & $(0.538)$ & $(0.424)$ & $(0.803)$ \\
\hline \multirow[t]{2}{*}{ attitude } & 0.117 & -0.188 & $0.534^{\star * *}$ & 0.082 & 0.228 \\
\hline & $(0.122)$ & $(0.191)$ & $(0.188)$ & $(0.145)$ & $(0.284)$ \\
\hline \multirow[t]{2}{*}{ expectation } & 0.190 & -0.287 & 0.380 & 0.170 & -0.042 \\
\hline & $(0.195)$ & $(0.309)$ & $(0.232)$ & $(0.240)$ & $(0.332)$ \\
\hline \multirow[t]{2}{*}{ social } & $0.199^{* *}$ & 0.150 & $0.474^{* * *}$ & $0.250^{\star \star}$ & -0.075 \\
\hline & $(0.081)$ & $(0.194)$ & $(0.162)$ & $(0.101)$ & $(0.141)$ \\
\hline \multirow[t]{2}{*}{ population } & $0.156^{\star * *}$ & 0.101 & $0.236^{* * *}$ & $0.167^{* * *}$ & 0.002 \\
\hline & $(0.048)$ & $(0.088)$ & $(0.069)$ & $(0.059)$ & $(0.095)$ \\
\hline \multirow[t]{2}{*}{ Informal } & $0.424^{\star * *}$ & $0.474^{* * *}$ & $0.458^{* * *}$ & $0.393^{* * *}$ & $0.699^{* * *}$ \\
\hline & $(0.066)$ & $(0.084)$ & $(0.101)$ & $(0.072)$ & $(0.155)$ \\
\hline \multirow[t]{2}{*}{ income } & -0.135 & -0.161 & -0.155 & $-0.177^{\star}$ & 0.128 \\
\hline & $(0.085)$ & $(0.102)$ & $(0.119)$ & $(0.103)$ & $(0.194)$ \\
\hline \multirow[t]{2}{*}{ formal } & 0.113 & $0.636^{*}$ & -0.360 & 0.267 & -0.048 \\
\hline & $(0.248)$ & $(0.352)$ & $(0.437)$ & $(0.297)$ & $(0.449)$ \\
\hline \multirow[t]{2}{*}{ region } & $-0.323^{\star *}$ & $-0.792^{\star * *}$ & -0.115 & $-0.368^{\star}$ & 0.097 \\
\hline & $(0.137)$ & $(0.253)$ & $(0.185)$ & $(0.199)$ & $(0.295)$ \\
\hline \multirow[t]{2}{*}{ Constant } & $-5.758^{\star \star \star}$ & -3.984 & $-9.378^{* * *}$ & $-5.986^{* * *}$ & $-7.001^{* * *}$ \\
\hline & $(1.420)$ & $(2.484)$ & $(2.107)$ & $(1.687)$ & $(2.647)$ \\
\hline observation & 429 & 173 & 256 & 305 & 124 \\
\hline
\end{tabular}

Note: ${ }^{* *},{ }^{* *}$ and ${ }^{*}$ are significant at the significance level of $1 \%, 5 \%$ and $10 \%$ respectively; The Numbers in brackets are standard errors. 
subsidies, subsidies variables influence on family business in the whole samples, the low social network group and grain of grain is still significant, and the influence direction consistent with that of the regression results in Table 2, that model to estimate the result has stronger robustness. The regression results are again verified: agricultural subsidies significantly reduce the probability of family entrepreneurship. And the effect of agricultural subsidies for home businesses probability exists heterogeneity: agricultural subsidies significantly reduced the low social network group and food of producing probability of family business, but did not significantly reduce the high social network group and the family business probability of major grain producing areas. Private lending helps families to start businesses; Formal finance only promotes family entrepreneurship in high social networking groups.

An empirical analysis of the data classification, this paper not only done on the impact of agricultural subsidies on family business probability regression analysis, the whole samples further breakdown data: according to the social network of the data is divided into "high social network group" and "low social network group", according to whether the data is divided into major grain producing areas to major grain producing areas and grain are not producing, and it is concluded that agricultural subsidies influence on probability of family business in two groups of samples are heterogeneous. This is actually a robustness test.

Through variable substitution and data classification, this paper proves that the regression results of agricultural subsidies on family entrepreneurial probability have strong robustness.

\section{Conclusions and Policy Recommendations}

\subsection{Conclusion}

Based on Chinese family financial investigation data in 2011, this article system in agricultural subsidies on non-agricultural production behavior studied the influence of family entrepreneurship, the mechanism of influence on agricultural subsidies and family business analysis and verification, getting the following conclusion:

First, based on the regression results of the whole sample, it can be seen that agricultural subsidies significantly reduce the probability of family entrepreneurship. In particular, for every 1 unit of agricultural subsidy, the probability of family entrepreneurship is reduced by $15.6 \%$. Private lending significantly increased the probability of family entrepreneurship. This partly explains the lack of formal credit support for rural households, which means that there are credit constraints.

Second, the influence of the agricultural subsidy for home businesses probability exists heterogeneity: agricultural subsidies significantly reduced the low social network group and food of producing probability of family business, but did not significantly reduce the "high social network group" and the major 
grain-producing areas and family business. Household population and social networks at the same time for family business probability influence also exist heterogeneity: it has significantly improved the low social network group and probability of major grain producing areas of family business, but for the high social network group and food not producing is not significant.

Third, through further empirical research, this paper finds and verifies the mechanism that agricultural subsidies affect the probability of family entrepreneurship: agricultural subsidies-raising agricultural income-reduces the probability of entrepreneurship. At the same time, the robustness test is carried out by means of variable substitution and data classification, which proves that the conclusion of this paper has strong robustness.

\subsection{Policy and Suggestions}

This article from the perspective of agricultural subsidies to entrepreneurship and influence mechanism research, not only helps to deepen the understanding of entrepreneurship influence factors, but more helps to promote the scientific and reasonable agricultural subsidy policy and entrepreneurship policy formulation and perfection. Based on the previous empirical results, the following recommendations are made:

First, give full play to comparative advantages and implement regional differential subsidy policies. Firstly, compared with the non-major grain producing areas, the main producing areas have the advantages of natural environment, production resources, agricultural science and technology, production experience and so on. According to the regression results, the agricultural income effect of the same standard is more obvious in the main producing areas than the non-main producing areas. Therefore, the state should continue to increase agricultural subsidies to major grain-producing areas, improve the precision of agricultural subsidies and encourage farmers to engage in professional production. Second, for not producing food, due to its natural environment, agricultural machinery science and technology development level relative disadvantages with the producing the same amount of farm subsidies and the effect resulted from will sell at a discount greatly, so the country can be used to increase the grain of farmer entrepreneurship subsidy policy support, encourage non-agricultural production activities, in order to promote the development of the rural third industry.

Second, vigorously develop rural finance and improve rural credit environment. The global entrepreneurship monitor 2015/2016 annual report pointed out that Chinese entrepreneurs to get the sources of venture capital are family and friends, bank loans, risk investment, the government projects and the raise is the source of funds, but the proportion is still lower than most of the innovation driven economy. Thus, capital constraint is one of the major difficulties that entrepreneurs face in undertaking entrepreneurial activities. By the regression results in this paper, it can be seen that the folk lending in all the sample and 
subsample return cash is very significant, suggesting that for rural households, if they want access to formal financial loan, it is difficult, so is the credit constraints. So much of that will be mitigated by private lending. Therefore, the state should vigorously develop inclusive finance, represented by small and micro finance, and create a favorable credit environment for rural households.

\section{References}

[1] (2015) Government Work Report. http://www.gov.cn/guowuyuan/2015-03/16/content_2835101.htm

[2] Zhao, M., Li, W. and Li, S. (2010) The Thought and Countermeasure of Perfecting Agricultural Subsidy Policy-Take Shan Dong Province as an Example. Dongyue Review, 31, 48-52.

[3] Fan, B. (2015) Effect Evaluation and Improvement Measures of the Subsidy Policy of Financial Benefit. Farmers Finance Research, 4, 18-21.

[4] Zhang, Q. (2010) The Influence of Agricultural Subsidy Policy on Farmer Income and Countermeasure-Take Hu Nan For Example. Value Engineering, 29, 120-122.

[5] Gao, Y. (2010) Evaluation of Direct Subsidy Efficiency Based on DEA Model. Journal of Xihua University (Philosophy and Social Science Edition), 29, 92-96 + 101.

[6] Ceng, F. and Zhu, Q. (2010) The Historical Investigation and Status Analysis of China's Agricultural Subsidy Policy since the Reform and Opening up. Journal of China Petroleum University (Social Science Edition), 26, 41-45.

[7] Wang, X. and Zhao, L. (2010) An Empirical Study on the Income Effect of Agricultural Subsidies in China. China Securities Futures, No. 6, 87-88.

[8] He, S. (2012) Analysis of Agricultural Support Policy Effect in China. Statistical Study, 29, 43-48.

[9] Li, J. and Xu, Y. (2015) To Explore the Efficiency Loss of Agricultural Subsidy Policy from the Perspective of Farmers' Income. Statistical Study, 32, 57-63.

[10] Li, M. and Xu, Y. (2012) The Effect of Agricultural Subsidy Policy on the Allocation of Household Production Factors of Farmers. Journal of Zhong Kai Agricultural Engineering College, 25, 55-60.

[11] Lv, W., Zhang, X. and Wang, W. (2015) Agricultural Machinery and Equipment Purchase Subsidy, Agricultural Production Efficiency and Rural Labor Transfer. Rural Economy of China, No. 8, 22-32.

[12] Zhong, H., Chen, S. and Xu, C. (2013) Structural Change, Relative Price of Factors and Farmers' Behavior-Theoretical Model of Agricultural Subsidies and Empirical Evidence. Financial Research, No. 5, 167-180.

[13] Sun, W. and Zhai, Y. (2016) The Influence of Agricultural Subsidy Policy on Farmer's Agricultural Production and Operation Intention. Take Liaoning Province as an Example. The Agricultural Economy, No. 12, 118-120.

[14] Jiang, X., Zheng, X., Hong, Y. and Liu, W. (2017) The Subsidy Policy, the Family Endowment Characteristic and the Forestry Scale Efficiency-Take 324 Oil Tea Micro Survey Data as an Example. The Southeast Academic, 5, 174-181.

[15] Shi, X., Liu, W. and Dai, Y. (2017) The Empirical Analysis of the Influence of Subsidy Policy on the Decision-Making Behavior of Farmers' Oil Tea Planting. The Forestry Economic, 39, 94-99.

[16] Jiang, D., Zhu, M. and Wu, G. (2017) Income Subsidy Raises the Technical Effi- 
ciency of Wheat Production in China-Empirical Evidence Based on Stochastic Frontier Function and Technical Efficiency Loss Function. Agricultural Modernization Research, 38, 15-22.

[17] Hou, L., Sun, Q. and Mu, Y. (2012) Analysis on the Influence of Agricultural Subsidy Policy on the Source Pollution of Agriculture-From the Perspective of Fertilizer Demand. Journal of Agricultural University of China, 17, 173-178.

[18] Yu, W., Tu, Y. and Yu, H. (2017) The Empirical Study on the Pollution Effect of Fertilizer Source by Agricultural Subsidies-Based on Provincial Panel Data. The Rural Economy, No. 2, 89-94.

[19] Zhu, H. and Kang, L. (2015) Financial Environment, Policy Support and Farmers' Willingness to Start a Business. Rural Observation in China, No. 5, 24-33 + 95-96.

[20] Wang, Z. and Cai, L. (2016) Does Internet lending Support Working Class Entrepreneurship?-Research Based on P2PLending Platforms. Research in Financial Economics, 31, 85-95.

[21] Ao, K. (2016) Liquidity Constraints and Entrepreneurship in Rural China. Southwest University of Finance and Economics, Chengdu.

[22] Chen, Y. and Cui, J. (2016) Research on the Hybrid Financing Behavior of Self-Employed Households. Journal of Xi an University of Electronic Science and Technology (Social Science Edition), 26, 43-51.

[23] Yang, Y. (2013) Research on China's Entrepreneurial System from the Perspective of Law and Economics. Shanxi University of Finance and Economics, Taiyuan.

[24] Chen, G. (2015) Regulation and Entrepreneurship-Microscopic Evidence from China. Management of the World, No. 5, 89-99 + 187-188.

[25] Ma, S. and Meng, X. (2016) Labor Cost and Rural Family Entrepreneurship: An Empirical Study Based on Enterprise Endowment Insurance Contributions. Journal of Economic, 3, 110-137.

[26] Wu, X., Wang, M. and Li, L. (2014) Does China's High Housing Prices Discourage Entrepreneurship? Economic Research, 49, 121-134.

[27] Tian, B. and Wu, X. (2014) The Spillover Effect of FDI on International Entrepreneurship-An Empirical Study Based on GEM Panel Data. Review of Finance and Economics, No. 8, 3-9.

[28] Tian, B. and Chen, Z. (2016) Regional Difference of Entrepreneurial Activity in China-Based on PLS Analysis. Soft Science, 30, 11-15.

[29] Ruan, R., Zheng, F. and Liu, L. (2014) The Power of Faith: Is Religion Good for Entrepreneurship? Economic Research, 49, 171-184.

[30] Zhao, P. and Wang, H. (2015) Analysis on the Impact of Social Capital and Religious Belief on Rural Family Entrepreneurship. Journal of Yunnan Nationalities University (Philosophy and Social Science Edition), 32, 67-72.

[31] Yu, Y., Yang, X. and Zhang, M. (2018) Corruption Regulation and Mass Entrepreneurship and Innovation: Empirical Evidence from Transnational (Regions). $\mathrm{Hu}$ manities Magazine, No. 1, 37-50.

[32] Zheng, X. and Zhou, X. (2018) How Do Social Norms Activate Entrepreneurial Activity? The Microscopic Evidence from China's "National Entrepreneurship" Decade. Economics (Quarterly), 17, 189-220.

[33] Zhang, B., Hu, J. and Fan, C. (2015) Social Network, Information Acquisition and Family Business Income-An Empirical Study Based on the Perspective of Urban and Rural Differences in China. Economic Review, 5, 52-67.

[34] Liu, M., Chen, X. and Xin, S. (2015) The Theoretical Model of Entrepreneurial 
Path-A Multi-Case Study Based on the New Generation of Migrant Workers. Financial Research, No. 3, 96-103.

[35] Li, J. and Li, H. (2016) The Impact of Housing on Rural Household Entrepreneurship: Evidence from CHFS. China's Economic Problems, No. 2, 53-67.

[36] Yang, N. (2015) The Relationship between Risk Attitude, Self-Employment and Enterprise Benefit Is Based on the Empirical Research of CHFS. Commercial Economic Research, No. 17, 102-104.

[37] Xu, Y. and Zhang, L. (2015) The Effect of Social Endowment Insurance on Rural Family Business and Income. China's Labor, No. 24, 88-93.

[38] Li, X., Ma, S. and Deng, X. (2015) Civil Servant Family, Entrepreneurship and Rent-Seeking Motivation. Economic Research, No. 50, 89-103.

[39] Barnum, H.N. and Squire, L.A. (1979) A Model of an Agricultural Household: Theory and Evidence. World Bank Occasional Paper, No. 27, 105-107.

[40] Squire, S.I. and Strauss, J. (1986) An Agricultural Household Models: Extensions, Applications and Policy. American Journal of Agricultural Economics, 69, 123-129.

[41] Ahearn, C., El-Osta, H. and Dewbre (2006) The Impact of Coupled and Decoupled Participation Government Subsidies on Off-Farm Labor Participation of US Farm Operators. American Journal of Agricultural Economics, 88, 393-408. https://doi.org/10.1111/j.1467-8276.2006.00866.x

[42] Anderson, K. (2009) Distortions to Agricultural Incentives. Eastern European Economics, 48, 79-109. https://doi.org/10.2753/EEE0012-8775480105

[43] Wu, L. and Liu, T. (2012) Research on Food Subsidy and Non-Farm Employment Behaviors Peasant Household. China's Population Resources and Environment, 22, $80-86$.

[44] Zeng, Y. (2016) Study on the Policy Effect of Direct Subsidy of Chinese Agriculture. Huazhong University of Science and Technology, Wuhan.

[45] Hennessy, T.C. (2008) Assessing the Policy on Economics. Irish Farmers' off Farm Labor Impact of the Decoupling Reform of the Common Agricultural Market Participation Decisions. Journal of Agricultural, 59, 41-56.

[46] Mu, Y. and Wang, Y. (2008) Simulation Analysis of the Effect of Agricultural Subsidy Policy in China. Economic Problems, No. 11, 87-89.

[47] Paulson and Townsend (2004) Entrepreneurship and Financial Constraints in Thailand. Journal of Corporate Finance, 10, 229-262.

[48] Weng, C. and Zhang, B. (2015) The Impact of Credit Constraints on the Choice of Chinese Rural Households-Based on CHFS Survey Data. Economic Science, No. 6, 92-102.

[49] Cao, S., Lin, H. and Cao, H. (2012) The Change Trend of Agricultural Subsidy Policy in China and Its Impact Analysis. Journal of Public Administration, 9, 55-63.

[50] Wang, O. and Yang, J. (2014) The Effects of Agricultural Subsidies on Grain Production in China. China's Rural Economy, 5, 20-28.

[51] Yang, X., Leng, Y. and Zong, Y. (2010) Analysis on the Influencing Factors of the Implementation Effect of Agricultural Subsidy Policy-Based on the Survey of 376 Farmers in Hubei Province. The Rural Economy, 1, 20-22.

[52] Wu, H., Huo, Z. and Zang, K. (2015) Analysis on the Impact of Agricultural Subsidies on Farmers' Agricultural Production Behavior-An Empirical Study from Rural Hubei Province. Journal of Huazhong Agricultural University, 5, 25-31.

[53] Wang, X.B. (2007) Labor Allocation in Transition: Evidence from Chinese Rural 
Households. China Economic Review, 15, 287-308.

https://doi.org/10.1016/j.chieco.2007.02.004

[54] Ma, G. and Yang, E. (2011) Social Network, Informal Finance and Entrepreneurship. Economic Research, 46, 83-94.

[55] Buera (2009) A Dynamic Model of Entrepreneurship with Borrowing Constraints: Theory and Evidence. Annals of Finance, 5, 443-464.

[56] Liu, Y., Ma, J. and Jia, N. (2015) Empirical Research on Family Entrepreneurship and Credit Constraints Based on CHFS. Journal of Sichuan Normal University, 42, 83-89. 